\title{
Identification of Progastrin in Gastrinomas, Antrum, and Duodenum by a Novel Radioimmunoassay
}

S. Pauwels, H. Desmond, R. Dimaline, and G. J. Dockray

Medical Research Council Secretory Control Group, University of Liverpool, Liverpool, England, United Kingdom; and Department of Nuclear Medicine, Louvain Medical School, Brussels, Belgium

\begin{abstract}
Recent studies on the gene sequence encoding the human pyloric antral hormone, gastrin, indicate a precursor of 101 residues. We have now raised antibodies to a synthetic analogue corresponding to (Tyr)-human progastrin COOH-terminal pentapeptide. The antibodies could be used in radioimmunoassay to measure this peptide, but they did not react with corresponding fragments of procholecystokinin, porcine progastrin, or other human progastrin-derived peptides, notably heptadecapeptide gastrin (G17), and 34-residue gastrin (G34). Radioimmunoassay of human antral and duodenal extracts revealed a major peak of activity that corresponded to the native $\mathrm{COOH}$-terminal fragment of progastrin, and occurred in approximately equimolar amounts with COOH-terminal G17 immunoreactivity. In addition, there was a minor peak of apparently higher molecular weight material. In some gastrinomas the latter material was the predominant immunoreactive form, and it occurred in higher molar concentrations than any other form of gastrin. Digestion of this material with trypsin liberated peptides that reacted with antibodies specific for the $\mathrm{NH}_{2}$-terminus of $\mathbf{G 3 4}$, and G17. On this basis the high molecular weight component was identified as a form of gastrin that extended from the $\mathrm{COOH}$-terminus of the precursor to a point at least beyond the $\mathrm{NH}_{2}$-terminus of $\mathbf{G} 34$, and probably included the entire progastrin sequence. The results suggest differences in posttranslational processing pathways of progastrin in antrum, duodenum, and gastrinomas. They also indicate that the present experimental approach allows the identification of progastrin-like substances, which should open the way to studying the mechanisms of gastrin biosynthesis.
\end{abstract}

\section{Introduction}

Recently the complementary DNA (cDNA) ${ }^{1}$ sequences complementary to the messenger RNA (mRNA) encoding porcine and human preprogastrin have been elucidated (1-4). These in-

Address correspondence to Dr. Dockray, Physiological Laboratory, University of Liverpool, Brownlow Hill, P. O. Box 147, Liverpool, L69 3BX, United Kingdom.

Received for publication 26 August 1985.

1. Abbreviations used in this paper: $\mathrm{CCK}$, cholecystokinin; cDNA, complementary DNA; G17, heptadecapeptide gastrin; G34, 34-residue gastrin; HPLC, high pressure liquid chromatography; mRNA, messenger RNA; NT G34, $\mathrm{NH}_{2}$-terminal fragment of G34; RSAEDEN, human progastrin 95-101; TFA, trifluoroacetic acid; TPCK, $N$-tosyl-L-phenylalanine chloromethyl ketone; YAEDEN, Tyr ${ }^{96}$ human progastrin 97-103.

J. Clin. Invest.

(c) The American Society for Clinical Investigation, Inc.

0021-9738/86/02/0376/06 \$1.00

Volume 77, February 1986, 376-381 dicate precursor peptides of 104 and 101 residues, respectively. In both instances there is a single copy of the sequence corresponding to 34-residue gastrin (G34), or big gastrin, isolated from pig antral mucosa and human gastrinoma tissue by Gregory and Tracy $(5,6)$. It has been appreciated for some time that G34 was a probable precursor of the major form of gastrin in antral tissue extracts, the heptadecapeptide, G17 (6)..The latter, together with an $\mathrm{NH}_{2}$-terminal fragment (NT G34), is generated by tryptic cleavage of $\mathrm{G} 34$ at pairs of Lys residues $(6,7)$. In preprogastrin, $\mathrm{G} 34$ is extended at both $\mathrm{NH}_{2}$-terminal and $\mathrm{COOH}$-terminal ends by peptide sequences that may be designated cryptic peptides A and B, respectively (Fig. 1). Recently, antibodies to porcine cryptic peptides $A$ and $B$ were used to identify and localize these peptides in pig antrum $(8,9)$. However, these antibodies do not react with the human cryptic peptides due to species differences in amino acid sequence (Scheme I). We have now developed a radioimmunoassay using antibodies to a synthetic analogue of human cryptic peptide $B$, and have used it together with assays for G17 and NT G34 to identify the peptides in extracts of human antrum, duodenum, and gastrinoma. Our results indicate the presence in these tissues of material corresponding to cryptic peptide $B$ and to a larger peptide that may be intact progastrin and that in some gastrinomas is the predominant immunoreactive form.

\section{Methods}

Peptides. The hexapeptide Tyr-Ala-Glu-Asp-Glu-Asn (YAEDEN in the single-letter notation) was purchased from Peninsula Laboratories, Inc., Belmont, CA, in the form of crude synthetic material. It corresponds to (Tyr)-human progastrin 97-101 (Scheme I). The amino acid sequences in Scheme I are aligned from the Phe residue destined to become the $\mathrm{COOH}$-terminal Phe amide of gastrin or cholecystokinin (CCK). Cleavage at the arginine residues liberates cryptic peptide B, which in each case, starts with the tripeptide Ser-Ala-Glu. The $\mathrm{COOH}$-terminal hexapeptide of human cryptic B substituted with Tyr in place of Ser, was used for immunization and radiolabeling in this study.

The YAEDEN hexapeptide was purified on high pressure liquid chromatography (HPLC) using an Altex system (Altex Scientific, Inc., Berkeley, CA) and either a $C_{18}$ Techsil column or $\mu$ Bondapak $C_{18}$ cartridge in a Z-module (Waters Associates, Millipore Corp., Milford, MA). Samples were applied in $0.1 \%$ trifluoroacetic acid (TFA) and eluted with a gradient of acetonitrile. The major peak with absorbance at $214 \mathrm{~nm}$ eluted with $6 \%$ acetonitrile; this material was used for immunization and labeling, and as the standard in the present study. It was characterized and standardized as follows: an initial estimate of concentration was made on the basis of $A_{280} \mathrm{~nm}$ calculated from the molar extinction coefficient for Tyr at this wavelength. A sample of $4.37 \mathrm{nmol}$ was then hydrolyzed in $6 \mathrm{M} \mathrm{HCl}$ containing $0.1 \%$ phenol, for $20 \mathrm{~h}$ at $108^{\circ} \mathrm{C}$. The hydrolysate was reacted with phenyl isothiocyanate, according to the method of Heinrikson and Meredith (10); the phenyl thiocarbamyl derivatives were separated on a Nova-pak column (Waters Associates), and the peaks of absorption at $254 \mathrm{~nm}$ integrated using a C-R3A Chromatopak (Shimadzu Scientific Instruments, Inc., Columbia, MD). The following amino acids were recovered: Asp, $9.5 \mathrm{nmol}$; Glu, $8.52 \mathrm{nmol}$; Ala, 4.03 


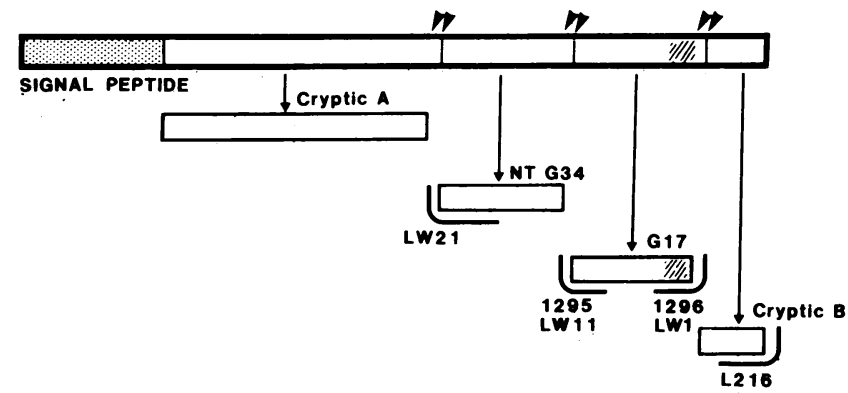

Figure 1. Schematic representation of human progastrin based on cDNA sequencing. Cleavage of the precursor at pairs of basic residues (arrows) would generate $\mathrm{G} 17$ (after $\mathrm{COOH}$-terminal amidation), NT G34, and two flanking peptides, designated cryptic peptides A and B. The specificity of the antibodies used for this study is shown. Note that $\mathrm{L} 216$ is specific for the $\mathrm{COOH}$-terminus of cryptic B and would be expected to react with $\mathrm{NH}_{2}$-terminally extended forms of this fragment, including intact progastrin. See text and references 11-13 for the specificity of the antibodies.

$\mathrm{nmol}$; Tyr, $4.35 \mathrm{nmol}$; these values are within $10 \%$ of the expected composition. The pure synthetic heptapeptide Arg-Ser-Ala-Glu-Asp-Glu-Asn (RSAEDEN) corresponding to human progastrin 95-101 was purchased from UCB Ltd. (Brussels, Belgium). Synthetic analogues of the $\mathrm{COOH}$ terminal fragments of porcine gastrin cryptic peptide $B$ (YGDQRP), and rat CCK cryptic peptide B (YEYPS) were obtained from Peninsula Laboratories, Inc., and Cambridge Research Biochemicals, Ltd. (Harston, Cambridgeshire, United Kingdom), respectively. Synthetic human G17 and 1-17 G34 were obtained from UCB Bioproducts (Brussels, Belgium) and synthetic human G34, from Fluka AG (Buchs, Switzerland); natural human G17 was a gift from Professor R. A. Gregory, University of Liverpool.

Tissue samples. Extracts were prepared from eight gastrinomas (four samples of primary tumors and four of metastatic tissue), antral mucosa ( $n=10)$, or duodenal tissue $(n=7)$ obtained at surgery. All the gastrinoma patients were diagnosed on the basis of a characteristic history of peptic ulcer disease, elevated basal plasma gastrin, positive secretin test, and basal acid output $>10 \mathrm{mmol} \cdot \mathrm{h}^{-1}$. Antral mucosa was obtained at resection for duodenal ulcer $(n=8)$, or carcinoma of the stomach ( $n$ $=2$ ). Duodenal samples, all of which were just distal to the sphincter of Oddi, were taken from patients undergoing Whipple's procedure. In all cases, the tissues were rapidly transported to the laboratory and either extracted immediately or frozen in liquid nitrogen and stored at $-80^{\circ} \mathrm{C}$ before extraction.

Extraction. Fresh, or deeply frozen, tissue was extracted in boiling water. Small pieces of tissue $(<0.1 \mathrm{~g})$ were added to vigorously boiling water and heated for $5 \mathrm{~min}$. Thereafter, the tissue was homogenized, the volume was made to $0.1 \mathrm{~g} \cdot \mathrm{ml}^{-1}$, and the extract was centrifuged. Supernatants were either stored frozen $\left(-20^{\circ} \mathrm{C}\right)$ or were lyophilized before further study. Re-extraction of pellets in either water or cold $3 \%$ acetic acid gave $<10 \%$ of original immunoreactivity.

Radioimmunoassay. Antibodies specific for human cryptic B were obtained by immunization of rabbits with YAEDEN. Peptide ( $570 \mathrm{nmol})$ was coupled to bovine thyroglobulin $(1.5 \mathrm{mg}$ ) by addition of $25 \mu \mathrm{lglu}$ taraldehyde (5\%) in phosphate buffer, $\mathrm{pH} 7.4,0.2 \mathrm{M}$. The mixture was
Human progastrin

Porcine progastrin

Rat pro CCK
-Phe-Gly-Arg-Arg-Ser-Ala-Glu-AspGlu-Asn

-Phe-Gly-Arg-Arg-Ser-Ala-Glu-GluGly-Asp-Gin-Arg-Pro

-Phe-Gly-Arg-Arg-Ser-Ala-Glu-AspTyr-Glu-Tyr-Pro-Ser.
SCHEME I incubated at $22^{\circ} \mathrm{C}$ for $30 \mathrm{~min}$, and then dialyzed against distilled water (4 liters, $4^{\circ} \mathrm{C}$ overnight). The incorporation of peptide into conjugate was $72 \%$, based on the recovery of a small quantity of ${ }^{125}$ I-labeled YAEDEN added to the reaction mixture. Four rabbits received $50 \mathrm{nmol}$ of peptide, emulsified in Freund's complete adjuvant and injected at multiple intradermal sites. They were boosted at 6-8 wk intervals with the equivalent of $25 \mathrm{nmol}$ of peptide and bleedings were taken from an ear vein 8-10 d after each boost. All rabbits gave antibodies binding labeled YAEDEN at 1:100 final dilution, but only one (L216) was of adequate titer for further studies. Antibody specificity was determined by comparison of the inhibition of binding by YAEDEN, RSAEDEN, and other peptides.

In initial studies, labeled peptide was prepared by the chloramine $T$ method, but in the work described here the iodogen method was used. Thus, $100 \mu \mathrm{l}$ of iodogen $\left(95 \mathrm{nmol} \cdot \mathrm{ml}^{-1}\right)$ dissolved in dichloromethane was dried in a glass tube. Phosphate buffer $(15 \mu \mathrm{l}, \mathrm{pH} 7.4,0.25 \mathrm{M})$ was then added, followed by peptide (1.0 $\mathrm{nmol}$ in $10 \mu \mathrm{l}$ phosphate buffer) and ${ }^{125} \mathrm{I}-\mathrm{Na}(5 \mu \mathrm{l}, 18.5 \mathrm{MBq}$ (Amersham International, plc, Amersham, Bucks, United Kingdom). The reaction mixture was incubated for 20 min at $22^{\circ} \mathrm{C}$, and the labeled peptide was purified by HPLC. The purification system employed a Hypersil $\mathrm{C}_{18}$ column Hypersil Technical, Ltd., Stockport, Cheshire, United Kingdom) eluted with a gradient of acetonitrile in $0.1 \%$ TFA. The peak of labeled peptide was diluted in assay buffer and stored at $-20^{\circ} \mathrm{C}$.

Assay incubations were made in a volume of $1.0 \mathrm{ml}$ sodium barbitone buffer $(0.02 \mathrm{M}, \mathrm{pH} 7.5)$ containing $0.05 \% \mathrm{wt} / \mathrm{vol}$ bovine serum albumin and $1 \mathrm{mg} \cdot \mathrm{ml}^{-1}$ ethylenediamine tetra-acetate. Antibody $\mathrm{L} 216$ was diluted 1:2,000, and used with $4,000 \mathrm{cpm}$ label. All assays included control tubes for nonspecific binding, which was always $<8 \%$, and standard curves of YAEDEN or RSAEDEN. Samples were diluted to give inhibition of binding between 20 and $80 \%$ of that in tubes containing antibody and label alone. Antibody-bound and free-label fractions were separated by addition of $100 \mu \mathrm{l}$ of a suspension of Amberlite CG400 resin (200 $\mathrm{g} \cdot$ liter $\left.^{-1}\right)$.

Samples were also assayed for $\mathrm{COOH}$ - and $\mathrm{NH}_{2}$-terminal $\mathrm{G} 17$ immunoreactivity and for $\mathrm{NH}_{2}$-terminal $\mathrm{G} 34$ immunoreactivity according to published methods (11-13).

Chromatography. Antral, duodenal, and tumor tissue extracts were fractionated by gel filtration on Sephadex G50s $(1 \times 100 \mathrm{~cm})$ equilibrated and eluted with $0.02 \mathrm{M}$ phosphate buffer, $\mathrm{pH} 7.4$, or $0.02 \mathrm{M}$ sodium barbitone, $\mathrm{pH} 8.2$. Recovery was $70-100 \%$ of immunoreactivity in all cases. Columns were calibrated with standard cryptic peptide B, G34, NT G34, and G17. In each run the elution position of immunoreactive peptide was determined relative to the void volume, detected by absorbance of protein at $280 \mathrm{~nm}$, and ${ }^{125} \mathrm{I}-\mathrm{Na}$ was added to the samples. The tubes corresponding to high molecular weight cryptic peptide B immunoreactive material were subsequently further purified on HPLC using a Z-module $\mathrm{C}_{18}$ ( $\mu$ Bondapak) cartridge (Waters Associates) in an HPLC system (Altex Scientific, Inc.) and eluted with a gradient of acetonitrile in $0.1 \%$ TFA. Tubes with cryptic B activity were diluted with 2 vol of $0.1 \%$ TFA and further run on a $\mu$ Bondapak phenyl cartridge.

Trypsinization. Two types of trypsinization experiments were done: (a) HPLC eluates containing high molecular weight cryptic B immunoreactivity were diluted 1:50 with ammonium bicarbonate, $0.1 \mathrm{M}$, and incubated with $N$-tosyl-L-phenylalanine chloromethyl ketone (TPCK)treated trypsin (10 $\mu \mathrm{g}$ from Worthington Diagnostics Div., Millipore Corp., Freehold, $\mathrm{NJ}$ ) for $2 \mathrm{~h}$ at $37^{\circ} \mathrm{C}$ and the reaction was terminated by $5 \mathrm{~min}$ in a boiling water bath. Samples were assayed with $\mathrm{NH}_{2}$-terminal G34, $\mathrm{NH}_{2}$-terminal $\mathrm{G} 17$, and $\mathrm{COOH}$-terminal $\mathrm{G} 17$ specific antibodies, as well as cryptic B antibodies, before and after digestion with trypsin. The samples were also rerun on HPLC and assayed with the antibodies just mentioned. (b) Extracts of antral mucosa and gastrinomas were digested with $100 \mu \mathrm{g} \cdot \mathrm{ml}^{-1}$ TPCK-treated trypsin by incubation in ammonium bicarbonate $0.05 \mathrm{M}$ at $37^{\circ} \mathrm{C}$ for $2.5 \mathrm{~h}$. The samples were then applied to Sephadex columns as described above.

Statistics. The concentrations of immunoreactivity in different tissue extracts, and the relative proportions of different components have been expressed as means \pm SEM. 


\section{Results}

Radioimmunoassay. Extracts of antral mucosa and gastrinoma inhibited binding of label to antibody L216 in parallel with the standard peptide (Fig. 2). The synthetic peptide RSAEDEN also diluted in parallel with YAEDEN, whereas peptides corresponding to the $\mathrm{COOH}$-terminal fragments of porcine progastrin and rat proCCK did not react significantly $(<0.001)$; other progastrin-derived peptides, i.e., G17, G34, and NT G34, were also inactive in the assay.

Antral mucosa. The concentration of cryptic B immunoreactivity in the antral extracts was $7.5 \pm 1.7 \mathrm{nmol} \cdot \mathrm{g}^{-1}(n=10)$ compared with $5.4 \pm 0.9 \mathrm{nmol} \cdot \mathrm{g}^{-1} \mathrm{COOH}$-terminal $\mathrm{G} 17$ activity. When antral extracts were fractionated on Sephadex G50 there was a major peak of cryptic B immunoreactivity that eluted in a similar position to the standard cryptic peptide and accounted for $84.3 \pm 2.1 \%$ of total activity (Fig. 3). A minor peak of cryptic $B$ immunoreactivity eluted just after the void volume and before G34, and contributed $12.3 \pm 1.6 \%$ to the total cryptic B immunoreactivity. In some column runs trace amounts of immunoreactivity ( $<2 \%$ total) emerged as a peak in the void volume, and as a peak just before the major peak. In all samples there were also major peaks corresponding to G17 and NT G34 identified by the appropriate antibodies. Intact G34 was $<5 \%$ total in all antral extracts.

Duodenum. Cryptic B immunoreactivity was also found in duodenal extracts, although concentrations were 5 to 20 times lower than in antrum (mean, $0.51 \pm 0.20 \mathrm{nmol} \cdot \mathrm{g}^{-1}, n=7$ ). The concentrations of $\mathrm{COOH}$-terminal G17 immunoreactivity in the same extracts $\left(0.42 \pm 0.16 \mathrm{nmol} \cdot \mathrm{g}^{-1}\right)$ were similar to those of cryptic B. The pattern of cryptic B immunoreactivity after separation on Sephadex G50 closely resembled that in the antral extracts (Fig. 4). In contrast, assays using $\mathrm{COOH}$-terminal G17 and $\mathrm{NH}_{2}$-terminal $\mathrm{G} 34$ antibodies showed that $\mathrm{G} 34$, rather than G17 and NT G34, predominated in the duodenal extracts.

Gastrinoma. The concentrations of cryptic B immunoreactivity in different tumor extracts ranged from 0.55 to 383 $\mathrm{nmol} \cdot \mathrm{g}^{-1}$ (mean, $108 \pm 53 \mathrm{nmol} \cdot \mathrm{g}^{-1} ; n=8$ ). By comparison, $\mathrm{COOH}$-terminal $\mathrm{G} 17$ immunoreactivity was $53 \pm 26 \mathrm{nmol} \cdot \mathrm{g}^{-1}$ (range, 0.03 to 217 ). In three cases the concentration of cryptic

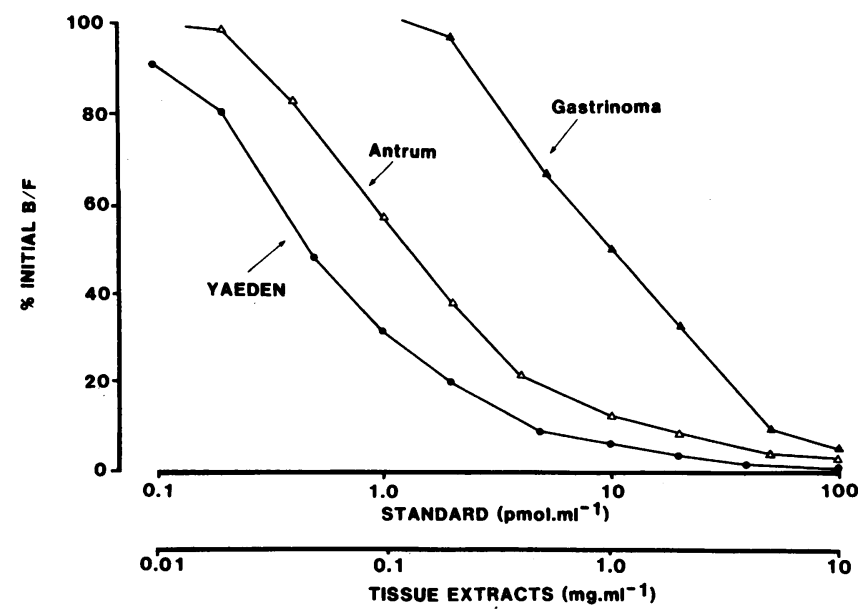

Figure 2. Inhibition of binding of label to antibody L216 by standard YAEDEN, and antral and gastrinoma extracts.

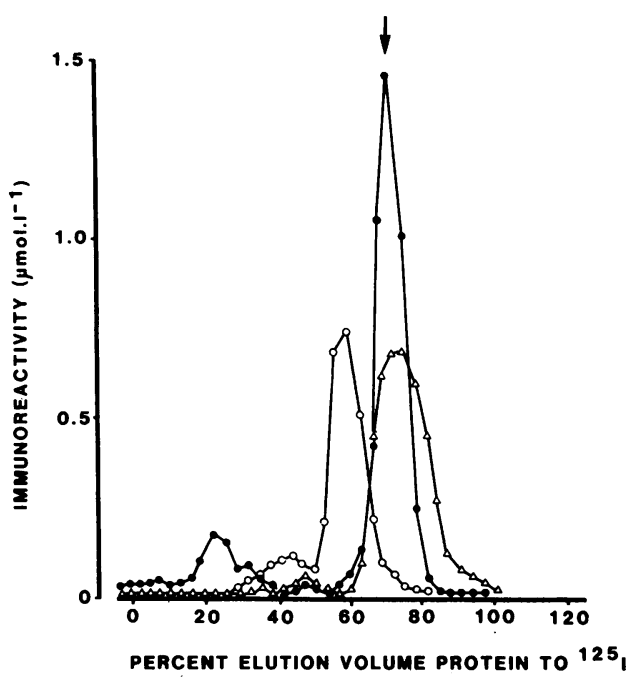

Figure 3. Separation on Sephadex G50 of an antral extract; the eluates were assayed with antibodies to cryptic B (•), NT G34 (0), and G17 $(\Delta)$. The arrow at the top indicates the elution position of synthetic standard cryptic B. In this system standard G34 elutes at $42 \%$, NT G34 at $58 \%$, and $\mathrm{G} 17$ at $70 \%$.

B immunoreactivity was within $\sim 30 \%$ of the concentration of COOH-terminal G17 immunoreactivity, but in four cases there was an excess of cryptic B immunoreactivity up to 18-fold greater than $\mathrm{G} 17$; in the remaining case $\mathrm{COOH}$-terminal $\mathrm{G} 17$ was $\sim 70 \%$ greater than cryptic B (Table I). Separation on Sephadex G50 revealed marked differences between tumors in the patterns of cryptic B molecular forms (Figs. 5 and 6). In all cases there was a peak eluting in a similar position to the standard, but unlike antral mucosa, this accounted for a variable proportion (20$75 \%$ ) of the total immunoreactivity (mean, $50.5 \pm 8.4 \%$ of total).

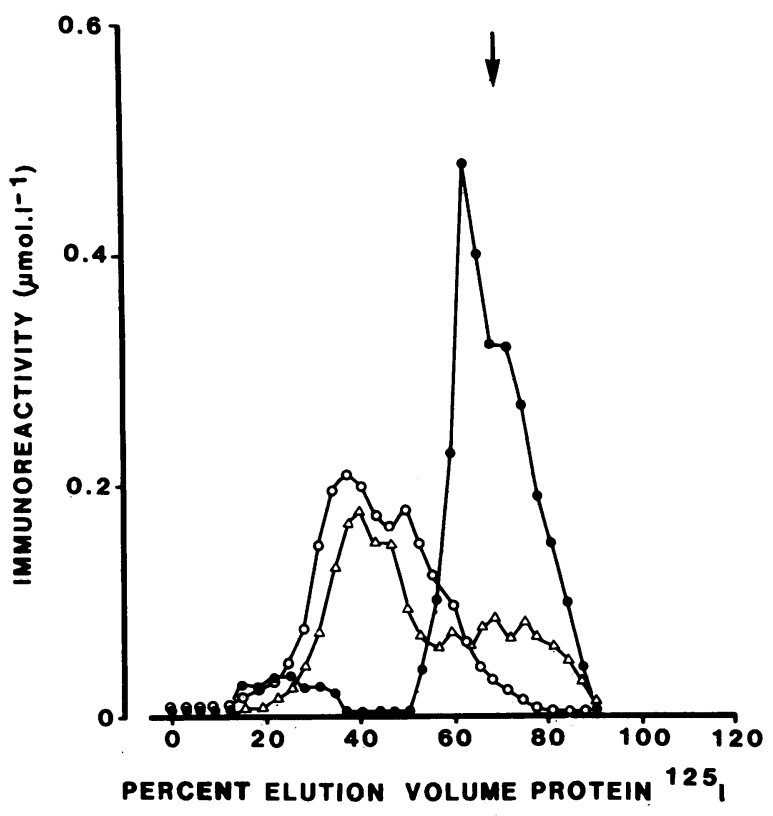

Figure 4. Separation on Sephadex G50 of a duodenal extract; tubes were assayed for cryptic B, NT G34, and COOH-terminal G17. See Fig. 3 for further details. 
Table I. Immunoreactive Gastrin in Gastrinoma Extracts

\begin{tabular}{|c|c|c|c|c|c|}
\hline $\begin{array}{l}\text { Pa- } \\
\text { tient* }\end{array}$ & $\begin{array}{l}\text { Plasma } \\
\text { gastrin }\end{array}$ & $\begin{array}{l}\text { Cryptic B } \\
\text { immuno- } \\
\text { reactivity }\end{array}$ & $\begin{array}{l}\text { "Authentic" } \\
\text { cryptic Bł }\end{array}$ & $\begin{array}{l}\mathrm{COOH} \text {-terminal } \\
\text { G17 immuno- } \\
\text { reactivity }\end{array}$ & $\begin{array}{l}\mathrm{NH}_{2} \text {-terminal } \\
\mathrm{G} 34 \text { immuno- } \\
\text { reactivity }\end{array}$ \\
\hline & $\mathrm{pmol} \cdot \mathrm{l}^{-1}$ & $n \mathrm{~mol} \cdot \mathrm{g}^{-1}$ & Percent & $\mathrm{nmol} \cdot \mathrm{g}^{-1}$ & $n \mathrm{~mol} \cdot \mathrm{g}^{-1}$ \\
\hline 1 & 590 & 84 & 71 & 52 & 61 \\
\hline 2 & 800 & 0.65 & 20 & 0.15 & 0.14 \\
\hline 3 & 900 & 10.5 & 67 & 17 & 10 \\
\hline 4 & 320 & 293 & 71 & 68 & 121 \\
\hline 5 & 100 & 0.55 & 32 & 0.03 & - \\
\hline 6 & $2,000,000$ & 91 & 48 & 70 & 96 \\
\hline 7 & 1,000 & 1.6 & 19 & 1.4 & 1.8 \\
\hline 8 & 910 & 383 & 75 & 217 & 255 \\
\hline
\end{tabular}

* Samples 1-4 were of primary tumors and 5-8 were of metastases. $\ddagger$ Percentage of total cryptic B immunoreactivity eluting from Sephadex G50 in the position of the major peak in antral extracts.

The early eluting peak accounted for most of the remaining activity; in three gastrinomas it was $>50 \%$, and in the group as a whole the mean was $39.7 \pm 6.5 \%(n=8)$. Minor peaks eluting in the void, and between the two main peaks, accounted for 6 and $2 \%$, respectively, of total activity. The predominant immunoreactive forms detected by antibodies to G17 and NT G34, corresponded to G17 and NT G34 in all the gastrinoma extracts studied.

HPLC and trypsinization. The high molecular weight cryptic B material in Sephadex eluates of gastrinoma extracts emerged as a single peak of immunoreactivity after reverse-phase HPLC (Fig. 7). The low molecular weight material was poorly retained

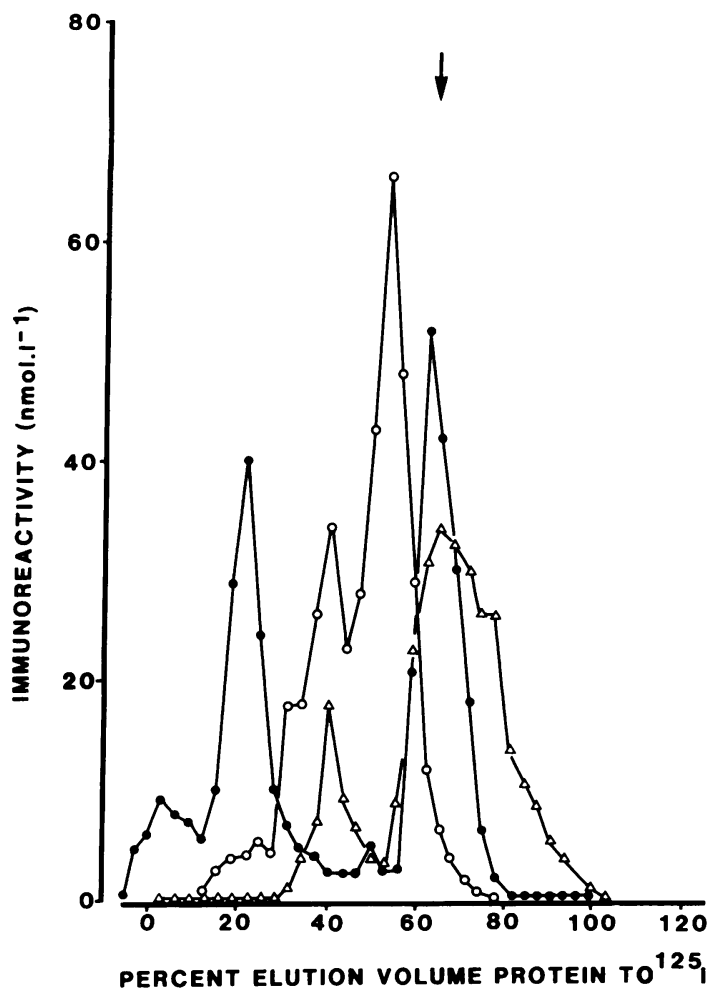

Figure 5. Separation on Sephadex G50 of a gastrinoma tumor extract. Tubes were assayed for cryptic B, NT G34, and COOH-terminal G17. See Fig. 3 for further details.

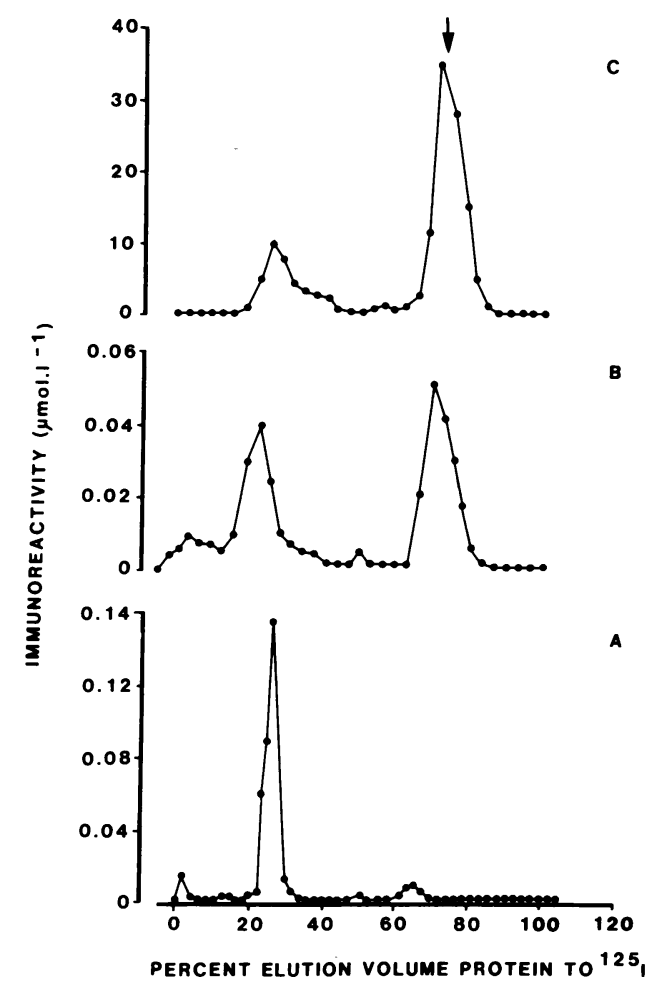

Figure 6. Patterns of cryptic B immunoreactivity in three different tumor extracts after Sephadex G50 separation. Note the ratios of the two major peaks of immunoreactivity vary from $>90 \%$ early eluting material $(A)$ to $70 \%$ late eluting material $(C)$. Minor peaks in the void volume and between the two main peaks can also be seen.

on HPLC and generally eluted with $0 \%$ acetonitrile (results not shown). The HPLC tubes corresponding to the high molecular weight cryptic peptide $\mathrm{B}$ contained trace amounts of activity in the $\mathrm{COOH}$-terminal and $\mathrm{NH}_{2}$-terminal $\mathrm{G} 17$ and G34-specific assays. With $\mathrm{NH}_{2}$-terminal $\mathrm{G} 34$ assays the activity was $\sim 10 \%$ that in the cryptic peptide B assay; with $\mathrm{NH}_{2}$-terminal $\mathrm{G} 17$ antibodies it was $\sim 1 \%$, and with $\mathrm{COOH}$-terminal $\mathrm{G} 17$ antibodies it was $0.1 \%$. Similar results were obtained when the material was rerun on a $\mu$ Bondapak phenyl cartridge. When tubes in the eluates of both $\mathrm{C}_{18}$ and phenyl columns were digested with trypsin, the concentrations of cryptic B and of COOH-terminal G17 immunoreactivity did not change (Fig. 7). However, there was a marked increase in immunoreactivity with $\mathrm{NH}_{2}$-terminal G17 and G34 antibodies. The concentration measured in the latter two assays after trypsin closely matched, in molar terms, those of cryptic peptide $B$. When the peak tubes were rerun on $\mathrm{C}_{18}$, separate peaks corresponding to $\mathrm{NH}_{2}$-terminal $\mathrm{G} 34, \mathrm{NH}_{2}$-terminal G17, and cryptic B immunoreactivity were resolved (Fig. 8 ). The latter was poorly retained by the column and emerged before the gradient. In further experiments, crude extracts of antrum and gastrinomas were trypsinized and run on Sephadex. In these experiments the early eluting peak of cryptic B immunoreactivity disappeared and there was a corresponding increase in the later eluting form (not shown).

\section{Discussion}

In this study antibodies to an analogue of the $\mathrm{COOH}$-terminal hexapeptide of progastrin have been used to identify and char- 


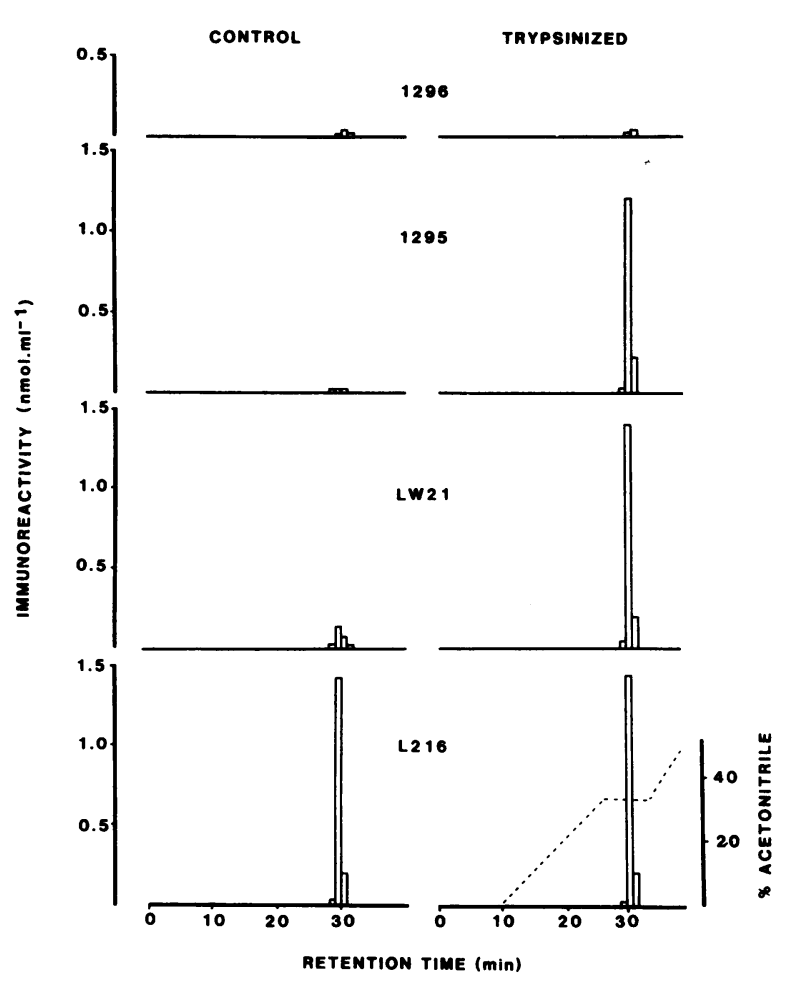

Figure 7. Separation on HPLC of the early eluting peak of cryptic B immunoreactivity in the gastrinoma extracts. Left, assays with antibodies specific for the $\mathrm{NH}_{2}$-terminus of G34 (LW21), G17 (1295), and $\mathrm{COOH}$-terminus of $\mathrm{G} 17$ (1296), showed trace amounts of activity in the same tubes as those containing cryptic B immunoreactivity (L216). Right, the same column eluates were individually digested with trypsin. This did not change the concentrations of cryptic B or $\mathrm{COOH}$-terminal $\mathrm{G} 17$ activity, but markedly increased $\mathrm{NH}_{2}$-terminal G17 and G34 immunoreactivity. Broken line indicates the gradient of acetonitrile.

acterize progastrin-related peptides in extracts of human gastrinoma, antrum, and duodenum. The peptide sequence was predicted from information on the structure of mRNA encoding human gastrin (2-4). Most of the presently available gastrin antibodies require some form of processing of the precursor, e.g., cleavage, amidation, etc., to generate immunoreactive material. In contrast, the antibodies developed in the present study have the particular advantage that they might be expected to react with intact progastrin. These antibodies have allowed us to identify in extracts of antrum and duodenum, material corresponding to the $\mathrm{COOH}$-terminal fragment of progastrin (cryptic peptide B). This is expected to be produced when the precursor is cleaved to yield G17. Similar material was also found in gastrinoma extracts. In addition, however, some gastrinomas contained abundant quantities of material that emerged before G34 on Sephadex and so was presumably of higher molecular weight. It reacted strongly with cryptic B antibodies and weakly with $\mathrm{NH}_{2}$ - and $\mathrm{COOH}$-terminal $\mathrm{G} 17$ and G34 antibodies. On the basis of this evidence, and of trypsinization results (see below), it has been tentatively identified as intact, or unprocessed, progastrin. This material also seems to occur in relatively low concentrations in antral extracts.

The results of previous studies have established the presence in antral extracts of peptides corresponding to G17 and NT G34 in approximately equimolar amounts (7). The concentrations
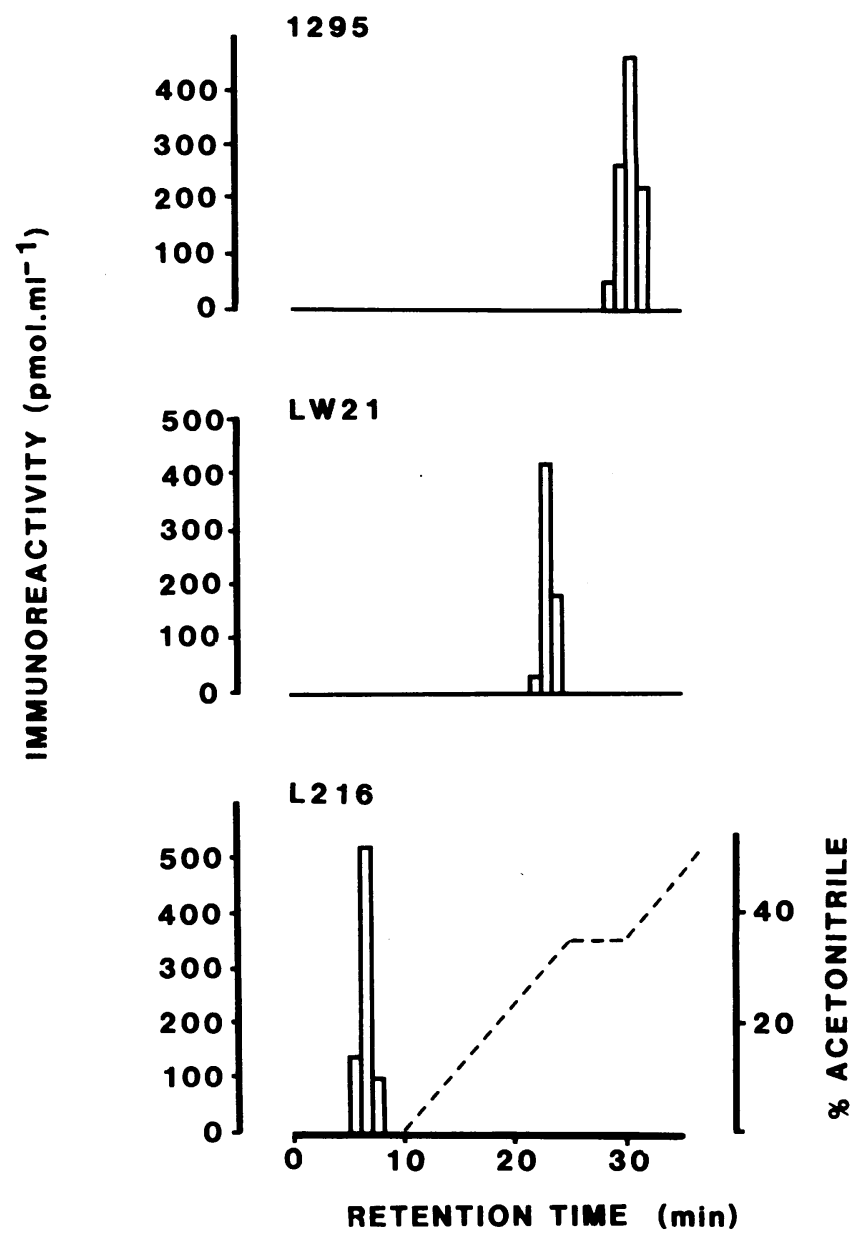

Figure 8. Separation on HPLC of the progastrin peak digested with trypsin. Note separate peaks of cryptic B (L216), $\mathrm{NH}_{2}$-terminal G34 (LW21), and $\mathrm{NH}_{2}$-terminal G17 immunoreactivity (1295). Acetonitrile gradient indicated by the broken line.

of cryptic B in the human antrum (present study) and pig antrum (9) were also similar to those of G17. The stoichiometry of these peptides is therefore compatible with the idea that they are produced from the same precursor. In some gastrinomas, however, there was a poor correlation between the molar concentrations of G17 and cryptic B immunoreactivity, and the latter was generally present in excess. The additional cryptic $B$ immunoreactivity can be accounted for by material corresponding to the cryptic peptide B sequence extended at its $\mathrm{NH}_{2}$ terminus. Digestion of this material with trypsin liberated peptides reacting with antibodies specific for the $\mathrm{NH}_{2}$ terminus of G34, and of G17. Evidently, therefore, this peptide extends from the cryptic B region to a point beyond the $\mathrm{NH}_{2}$ terminus of $\mathrm{G} 34$, and may possibly include the entire progastrin sequence. Recently Reeve et al. (14) reported in two gastrinomas unexpectedly high concentrations of peptides with amino acid sequences corresponding to the $\mathrm{NH}_{2}$ terminus of cryptic peptide $\mathrm{A}$. The high molecular weight cryptic peptide $\mathrm{B}$ immunoreactivity we have identified here may well extend into this sequence.

We have recently shown that antibodies specific for porcine progastrin cryptic peptide B react with two peptides in antral extracts that have the gel filtration properties of cryptic peptide B sequence (9). In the pig we were unable to identify material that might have corresponded to intact progastrin. In this regard, 
therefore, there is a difference between the pattern of immunoreactive forms in pig and man. The antral samples used for the present study were obtained from duodenal ulcer patients, and so the pattern of forms in normal human antral mucosa remains to be determined.

It is well established that there are different proportions of G17 and G34 in human antrum and duodenum. The latter often contains over $50 \%$ G34 compared with $<5 \%$ in antrum (1517). This can be interpreted as indicating different patterns of posttranslational processing of gastrin in antral and duodenal cells. It is of interest, however, that there were similar patterns of cryptic peptide B immunoreactivity in duodenum and antrum. In both cases the predominant material had the chromatographic properties of the $\mathrm{COOH}$-terminal fragment of progastrin. This suggests that the processing events involving cleavage of progastrin at the $\mathrm{COOH}$-terminus of $\mathrm{G} 17$ are more or less complete in both antrum and duodenum, whereas those at the $\mathrm{NH}_{2}$ terminus of G17 are incomplete in duodenum.

Further work is needed to establish the basis for the different patterns of progastrin-derived peptides in tissues expressing the gastrin gene. Two possibilities might explain the differences between gastrinomas and antral mucosa found in the present study. (a) There may be a biochemical failure in the processing pathways in some gastrinomas; and $(b)$ the rate of production of the precursor may exceed the maximal rate of processing so that newly synthesized material accounts for a higher proportion of the tissue content in some gastrinomas. Further chemical studies on the identity of the progastrins, and the determination of the secretory patterns of the different immunoreactive forms may help resolve these issues.

\section{Acknowledgments}

We are indebted to Drs. V. Varro, J. De Graef, and P. J. Kestens for generously providing samples of gastrinomas for these studies. Drs. J. Walsh and R. A. Gregory kindly donated antisera and peptides. Christine Williams helped prepare the manuscript, and Ms. M.-A. Lecroart provided technical assistance.

We are grateful to the Medical Research Council, and to North Atlantic Treaty Organization for financial support.

\section{References}

1. Yoo, J. O., C. T. Powell, and K. L. Agarwal. 1982. Molecular cloning and nucleotide sequence of full-length $\mathrm{CDNA}$ coding for porcine gastrin. Proc. Natl. Acad. Sci. USA. 79:1049-1053.
2. Boel, E., J. Vuust, F. Norris, K. Norris, A. Wind, J. F. Rehfeld, and K. A. Marcker. 1983. Molecular cloning of human gastrin cDNA: evidence for evolution of gastrin by gene duplication. Proc. Natl. Acad. Sci. USA. 80:2866-2869.

3. Kato, K., S. Himeno, Y. Takahashi, T. Wakabayashi, S. Tarui, and $\mathrm{K}$. Matsubara. 1983. Molecular cloning of human gastrin precursor cDNA. Gene (Amst.). 26:53-57.

4. Ito, R., K. Sato, T. Helmer, G. Jay, and K. Agarwal. 1984. Structural analysis of the gene encoding human gastrin: the large intron contains an Alu sequence. Proc. Natl. Acad. Sci. USA. 81:4662-4666.

5. Gregory, R. A., and H. J. Tracy. 1972. Isolation of two "big gastrins" from Zollinger-Ellison tumour tissue. Lancet. ii:797-799.

6. Gregory, R. A., and H. J. Tracy. 1975. The chemistry of the gastrins: some recent advances. In Gastrointestinal Hormones. J. C. Thompson, editor. University of Texas Press, Austin, TX. 13-24.

7. Dockray, G. J., C. Vaillant, and C. R. Hopkins. 1978. Biosynthetic relationships of big and little gastrins. Nature (Lond.). 273:770-772.

8. Jonsson, A.-C., and G. J. Dockray. 1984. Immunohistochemical localization to pyloric antral G-cells of peptides derived from porcine preprogastrin. Regul. Pept. 8:283-290.

9. Desmond, H., G. J. Dockray, and M. Spurdens. 1985. Identification by specific radioimmunoassay of two novel peptides derived from the C-terminus of porcine preprogastrin. Regul. Pept. 11:133-142.

10. Heinrikson, R. L., and S. C. Meredith. 1984. Aminoacid analysis by reverse-phase high performance liquid chromatography: precolumn derivatization with phenylisothiocyanate. Anal. Biochem. 136:65-74.

11. Dockray, G. J., and J. H. Walsh. 1975. Amino terminal gastrin fragment in serum of Zollinger-Ellison syndrome patients. Gastroenterology. 68:222-230.

12. Pauwels, S., G. J. Dockray, R. Walker, and S. Marcus. 1984. Nterminal tryptic fragment of big gastrin: metabolism and failure to influence gastrin 17-evoked acid secretion in humans. Gastroenterology. 86:86-92.

13. Pauwels, S., G. J. Dockray, R. Walker, and S. Marcus. 1985. Metabolism of heptadecapeptide gastrin in man studied by region specific antisera. J. Clin. Invest. 70:2006-2013.

14. Reeve, J. R., Jr., J. H. Walsh, R. K. Tompkins, D. Hawke, and J. E. Shively. 1984. Amino terminal fragments of human progastrin from gastrinoma. Biochem. Biophys. Res. Commun. 123:404-409.

15. Berson, S. A., and R. S. Yalow. 1971. Nature of immunoreactive gastrin extracted from tissues of gastrointestinal tract. Gastroenterology. 60:215-222.

16. Malmstrom, J., F. Stadil, and J. F. Rehfeld. 1976. Gastrins in tissue: concentration and component pattern in gastric, duodenal and jejunal mucosa of normal human subjects and patients with duodenal ulcer. Gastroenterology. 70:697-703.

17. Calam, J., G. J. Dockray, R. Walker, H. J. Tracy, and D. Owens. 1980. Molecular forms of gastrin in peptic ulcer: comparison of serum and tissue concentrations of G17 and G34 in gastric and duodenal ulcer subjects. Eur. J. Clin. Invest. 10:241-247. 